in any year, for considerations by the Court at its meeting the following February.

\section{Eligibility of nominees}

a. Candidates must either be Members of the College by Examination of more than five years standing, or Members who have been granted exemption from Examination.

b. The Fellowship is ordinarily awarded to a Member for unusual distinction in teaching, research, and/ or administrative ability, or for exceptional service to patients, especially where the supporting services have been inadequate. Sponsors are therefore asked to indicate any factors which go beyond the carrying out of consultant or academics duties by the candidates of their choice.

All sponsors and all successful candidates will be notified by letter of the decision of the Court of Electors.

Individuals elected to the Fellowship become entitled to use the designation FRCPsych after they have paid the prescribed registration fee.

\title{
Study tour to Hungary, 29 May-4 June 1989
}

\author{
Geoffrey Wallis, Consultant Psychiatrist, Fulford Grange Hospital, Rawdon, \\ Leeds LS19 6BA
}

Under the streets of Óbuda, which means Old Buda, on the west bank of the Danube, is a beautifully displayed and preserved group of Roman public buildings. They were at the boundary of the Roman Empire. Later Hungary became an outpost, from the opposite direction, of the Ottoman Empire and the Russian annexations.

It still is a political and cultural bridge between East and West Europe but to the resentment of Hungarian psychiatrists, the Russians have maintained a hold on Hungarian psychiatry by frequent surveillance visits by Russian psychiatrists in high office and by stipulating that Hungarian psychiatric libraries should contain the works of Lenin and Stalin, and that the syllabus for Hungarian psychiatric trainees should include the Russian language, whereas the Hungarian language approximates, if to any languages, to Finnish with some impact from the Turks. Russian psychiatrists had heard of our study tour and Professor Zharikov and a younger colleague came from Moscow to two symposia which the Hungarians and ourselves held jointly in Budapest. Silvery haired, charmingly mannered and persuasive Professor Zharikov, in an out of context address at the first of these symposia, emphasised that psychiatrists visiting Russia were welcome to see any patients in their hospitals. He maintained that he had received no report from a team of American psychiatrists who had visited Russia although several months had elapsed since that visit. Our Hungarian hosts felt that they had gained a point over the Russians in having the Royal College of Psychiatrists to visit them and the Editor of our Journal could have increased any Russian chagrin by observing in the second Budapest symposium that whatever the rights and wrongs of the matter if one wished to have one's work communicated worldwide one had to write in English or have access to translation into that language, and that nobody outside Russia knew of any Russian psychiatric research. Professor Zharikov continued to smile benignly.

Meanwhile outside psychiatry-some psychiatrists believe there is such a place-Russian influence was waning. We saw enough Red Stars on the buildings to realise how pervasive and repressive they must have been but they had become fewer. Imre Nagy, hanged for democratic activities in 1958 in a house very close to where some of us were accommodated in Pest, the flat part of Budapest to the east of the Danube, had been rehabilitated and was awaiting a funeral service with full honours in Matthias church. Russian soldiery was little in evidence in Budapest because most of its reduced strength was garrisoned unprovocatively elsewhere in the country. We were told that the Hungarians did not want it to retreat altogether because they hoped it would help to defend against an invasion, which they thought to be by no means impossible, by Rumania's repressive Ceausescu. Moreover the Hungarians were concerned about their many kinsfolk in Transylvania, which is the part of Rumania adjacent to its border with Hungary. Very ironically Hungary was taking down its frontier fence with Austria while Ceausescu was building a wall between Hungary and Rumania to stop a flood of Hungarians returning to their country of origin. 
There is a medical school in Debrecen, which is very close to the Rumanian frontier. Other medical schools are in Budapest, Pécs in the south-west and Szeged in the south-east, and we visited these three. The schools have produced a current strength of nearly 1,300 psychiatrists and neurologists. The total is expressed thus because of a bond between Hungarian psychiatrists and neurologists and the two disciplines did not separate into different associations until a few years ago. Hungary's population is 10.5 million, 2.1 million being in Budapest, and for every 100,000 there is a consultant psychiatrist. Although professors prefer to enrol males because of the probability that females would need maternity leave and we were told that if females take maternity leave for longer than three years they lose their jobs, $58 \%$ of the psychiatrists and neurologists are female. Radiology and pathology are unpopular because of their physical dangers.

The National Institute for Nervous and Mental Diseases in upper Buda, opened in 1868 after long delays, rises magnificently in pleasant leafy grounds in the upper Buda region. It has an academic department and some 1,400 beds in 16 psychiatric, two neurological and one rehabilitative departments. Ten of the psychiatric departments are 'regionally organised' and there are 22 psychiatric out-patient clinics. Other psychiatric beds in Budapest bring the total provision of these beds to 1.3 per 1,000 population and this figure is fractionally more than the corresponding one in the rest of the country.

In this hospital Pandy discovered the carbolic acid reaction with albumin in the cerebrospinal fluid. $\mathrm{He}$ was not a laboratory expert but an humanitarian psychiatrist. Also here Meduna induced epileptic fits with injections of camphor and then Cardiazol, thereby opening immensely therapeutic channels. Not all of Hungary's contributions to psychiatry are organic. Ferenczi, the "son of Freud", analysed Balint but left Budapest for Vienna in a great psychoanalytic interchange. That Balint's father had been a general practitioner may have stimulated him, after his coming to London in the early 1950s, to achieve his success in teaching psychotherapy to general practitioners. Franz Alexander emigrated to the USA. Thomas Szasz was a child of Budapest but he went to the USA when he was 18. Szondi departed for Switzerland in 1942 and until 1956 the communists banned his books in Hungary.

None of the wards in the Budapest hospital is locked and mentally abnormal offenders, except for a few who go to the hospital in Debrecen, are treated in prison, but some parts of the wards are more secure than others and as new patients become less disturbed they graduate to the more permissive parts. A single psychiatrist or policeman can admit patients formally and $50 \%$ of admissions are formal but if the admitting psychiatrist in the hospital disagrees with the admission, the patient goes home. If the patient does stay, after eight days the head of the psychiatric department has to decide whether to prolong the detention. The patient can then appeal to a judge and two independent psychiatrists, who, if the patient does not appeal, decide when six weeks have elapsed whether the detention should continue. These regulations are 60 years old and seem to work well. Throughout the hospital only $1 \%$ of patients are detained.

There seemed on the wards which we saw to be many patients in pyjamas and dressing gowns. White coats for the medical staff added somewhat to the institutional atmosphere but Professor Peter Gaszner, a lively and energetic guide, explained that the patients helped each other and that this process was encouraged by having six beds per room rather than one.

A national insurance system started in 1948 . The employer pays $43 \%$ of the contribution, which is independent of taxation at $\mathbf{4 0 \%}$. An endearing predilection of giving gifts blurs the distinction between state and private psychiatric practice but soon the giving of presents for private medical services may be legalised and then doctors would have to declare gifts for income tax. In any event, outside Budapest most psychiatrists are too busy to practise privately. Inflation runs at $30 \%$ and unemployment is starting but not among doctors, although the pay of their junior members is so poor that they have great difficulty in renting even the smallest flats and travelling abroad. On the other hand, transport and shopping for delights such as cherries, strawberries, paprika and musical records are remarkably cheap. A dash by taxi from outer Buda across the Danube to outer Pest cost us 100 forints, which is roughly equivalent to $f 1$.

The topic for the first of the symposia in Budapest was depression and its venue was the Psychiatric Institute's chapel, where the stained glass windows were pleasantly ornamental. Its height had been reduced by a ceiling, above which were the Institute's library and the tops of the same stained glass windows. The library had some books 120 years old and took 100 journals, among which we were assured that our Journal took top priority.

The Hungarian contributions to the symposium on depression were the need for a new nosological system, the heterogeneity of affective disorders, ECT, prophylaxis and lithium transport, while our members spoke on depression in old age and changes in the approach to depression. An interesting round room, lit by round wall lights, in the highest floor of a tuberculosis sanatorium which had become the Institute's Postgraduate Medical School, accommodated the other Budapest symposium, at which the leading Hungarian lights were Professor Erzsébet Moussong-Kovács, a clinical psychologist who had 
for many years been a central figure in psychiatric and psychological education, and Professor J. Füredi, President of the Hungarian Psychiatric Association. They and their colleagues described a four year course leading to registration in psychiatry. Afterwards the trainee could do a three year course in psychotherapy, one year being devoted to behavioural or cognitive methods or research. The Hungarians frankly admired our rotational training schemes.

From Budapest to Pécs we went by bus across fertile country peppered with red roses, stopping for lunch by the still water of enormous Lake Balaton. After a swim we embarked in a ferry for the southern shore. We spent the next two nights in a fascinating, picturesque and high 'castle' which originated as a Benedictine monastery founded by King Stephen I, the first King of Hungary, who was crowned on Christmas Day 1000. This 'castle' staged a symposium on suicide, in which Professor K. Ozsváth concluded from an epidemiological survey that the main reasons why the suicide rate in Hungary was by any criterion the highest in the world were that povery induced women to work for long hours, so that their babies were deprived of their love, and alcoholism was a "way of life". Drs Zoltán Rihmer and $\mathrm{J}$. Barsi showed in a study of 20 Hungarian counties that the county with the lowest suicide rate had the highest ratio of depression to schizophrenia, whereas in the county with the highest rate this ratio was the lowest - a finding that invites many interpretations. Professor Phil Seager gave a brilliant exposition indicating that the fluctuations in worldwide suicide rate were not easily explicable. The language at all the symposia was English and we wondered whether the lack of simultaneous translation accounted for a somewhat low Hungarian presence. The spacious medical university of Pécs had an impressive record of undergraduate education.

A morning's journey over the southern stretch of the Hungarian Danube took us to Szeged. Its university had started at Kolozsvár in Transylvania, which was then part of Hungary. A first world war treaty took Kolozsvár out of Hungary and in 1921 the university, meeting a 200 year old wish of the people of Szeged, moved there but in 1940 Hungary reannexed Kolozsvár, whither the university returned. However, the government founded a new university in Szeged and most of the teaching staff, including Albert Szent-Györgyi, who had won a Nobel prize for synthesising vitamin C, stayed in it. He and other Szeged giants of the medical sciences are commemorated in a collection of coins. Now, under the guidance of Professors János Sziard and Peter Molnar, of psychiatry and psychology respectively, medical students learn interviewing techniques, psychiatry is part of the curriculum for the whole of their fifth year and family doctors take courses in Balint-type therapy. The psychiatric hospital is outside the town and at the time of our visit was, except for a children's ward, oppressively crowded and bed and restraint orientated, but a marvellous general hospital near the university was about to open and on its fourth floor was a psychiatric department which was already well equipped, although a huge central well might later arouse anxiety in the staff. The staffing of this department would include 20 psychiatrists, six of them trainees.

We anticipated some curtailment of our time in Szeged because afterwards we had a long evening journey to Budapest but our Hungarian colleagues admirably resisted any such premature departure and in the Szeged cathedral, colourfully decorated with illustrations of Bible stories, a psychiatrist, Endre Mészáros gave us a moving recital of Purcell, Bach, Rossini and César Franck on the organ.

Thestaff of the British Embassy in Budapest gave us a cheerful reception and explained that the sizeable library there served the needs of a surprisingly large number of British in the city. From the environs of Matthias church in Buda we had splendid views of the island in and the bridges over the Danube and the Houses of Parliament, built to symbolise the grandeur of the Austro-Hungarian Empire and then called the biggest in the world. Pits from gunfire riddled many of the buildings, notably the columns on the edge of Heroes' Square. We saw the statue of Anonymous, representing the royal scribe who wrote the first Hungarian chronicles, and men playing chess on a board floating in an outdoor swimming bath.

A gallery in the psychiatric hospital in Budapest has some very high quality nightmarish paintings by patients and in a gallery in Pécs the works of Vasarely depicts animals in black and white that look just as though they are moving. In Pécs too a statue of Liszt gazes studiously from a balcony in the corner of a square while under the square is a fascinating Roman tomb decorated with representations of Christianity. In Szeged there are parks and riverside scenes extending from the attractive university campus.

A guide in the Petö Institute for patients with motor disabilities told us about the Institute and showed us round it. Petö started his work in 1945 and the first institute opened in 1950. The essence of the treatment, called 'conductive', is extremely hard and long intensive, physical, intellectual and emotional work, in a quiet, intense and devoted atmosphere, by the patients and their relatives and therapists. The therapists train for four years to become 'conductors' and the trainee 'conductor' of one group of children whom we saw was a girl from Birmingham, where the British Spastic Society has established a unit based on Petö principles. At the time of our visit the institute was treating 500 residential children and 1,000 out-patients and there is a suggestion that it will extend into another institute. The fees for nonHungarians vary from 200 to 600 forints a day. The 
claim for the success rate for children aged under six, judged by their improving so that they can compete with healthy peers, is $85 \%$. However, the institute does not accept patients with any psychiatric disorder.

For the College's Programmes and Meetings Committee the highly successful organiser-in-chief was Dr Cornelius Katona and all in our party of 37 were very deeply grateful to him and to the flexible and sensitive leadership of Professor Hugh Freeman.

Our Hungarian hosts, some of them on the organising committee, were at the utmost pinnacle of kind- ness, generosity, thoughtfulness and cheerfulness; for innumerable acts of escort and guidance we are particularly indebted to Dr Zoltán Rihmer, his junior Dr Katalin Vég, Dr Zsuzsanna Hada and her dentist husband Zsolt Fenyves. In Szeged, big bearded Dr Zoltán Janka was the soul of genial and patient direction. One evening in Budapest the Hungarians took us to dinner, mostly in their homes, in groups as small as two, and on this and other occasions we ate, drank and exchanged ideas magnificently at tables often decked with the Hungarian flag and the Union Jack.

\title{
Trauma and its Aftermath
}

\section{A report on the First Residential Conference of the Psychotherapy Section of the Royal College of Psychiatrists, held at Queens' College, Cambridge, 6-8 April 1989}

\author{
Marcus Johns, Consultant Psychiatrist, Tavistock Clinic, London NW3 5BA
}

This conference presented a wide ranging programme. Between them the speakers covered the disruptions and distortions in development in individuals, groups, institutions, and social structures as they covered the range of child abuse, survivors of disasters, health service crisis, the impact of AIDS, social disruption and psychotic processes.

The conference was programmed as "An exploration of the impact of trauma on the individual, family and society, from psycho-analytic, groupanalytic and sociological perspectives". This exploration was achieved, not only by the presentations of the speakers, but by skilful use of the small and large groups for discussions after the presentations. The stimulating effect of these groups was that conference members were required to engage in the difficult work of incorporating their understanding of the presentation into their own personal histories. This experiential work allowed the integration of other people's experiences with one's own, both in terms of conscious personal memories as well as some unconscious elements. Although this structure of the conference gave rise to some anxiety at first, the tasks generally seemed to be tackled well by the conference members and were certainly facilitated by small group conductors from the Institute of Group Analysis. The large group demonstrated yet again how difficult it is to remain task-centred and Colin James, as convenor of the group, had a difficult task.
The choice of Cambridge for the first residential conference was excellent and allowed many members to remind themselves and each other of previous life episodes, for good and bad, and to give others a tiny sample of an academic life that had been part of many fantasies. The only disappointment for members and for some speakers was that, because of the innovative use of the small groups, there was not the usual dialogue between speakers and audience that is valued by both sides. Nevertheless Jon Sklar and Andrew Powell must be congratulated for creating an involving and thought-provoking weekend which John Hook's administration ran efficiently, with the hard work of Jean Wales and Sue Prevost.

After the opening remarks of the organisers, Earl Hopper took us into the links between social structures, systems, group analysis and psycho-analysis with his paper on 'Social Trauma and Psychotic Anxieties'. He reminded us how social systems and groups are maintained by common attitudes and beliefs and that when these organisations are traumatised, the level of functioning regresses towards what in the individual would be seen as psychotic processes. He showed us how, in considering the unconscious life of groups, there could be a fourth basic assumption to set alongside Bion's pairing, fight-flight, and dependency. This fourth basic assumption is one of aggregation-massification. These are phenonema which occur when the 